\title{
Inhibition of the basal and oestradiol-stimulated mitotic activity of primary spermatogonia by melatonin in the testis of the frog, Rana esculenta, in vivo and in vitro
}

\author{
M. d'Istria, C. Palmiero, I. Serino, G. Izzo and S. Minucci* \\ Dipartimento di Medicina Sperimentale-Sezione di Fisiologia Umana e Funzioni Biologiche Integrate \\ 'F. Bottazzi' Facoltà di Medicina e Chirurgia, Seconda Università degli Studi di Napoli, \\ via Costantinopoli 16, 80138 Napoli, Italy
}

\begin{abstract}
Melatonin has a direct inhibitory effect on the basal and oestradiol-stimulated mitotic activity of primary spermatogonia in the testis of the frog, Rana esculenta. In this study oestradiol was used to induce spermatogonial proliferation to verify the anti-proliferative effect of melatonin. The colchicine metaphase arrest technique was used. The results obtained from in vivo experiments confirm that oestradiol increases the mitotic index of primary spermatogonia and, for the first time, indicate that melatonin has an inhibitory role on the proliferation of primary spermatogonia in the frog testis. Similar results were obtained from testes of melatonin-injected frogs that were exposed to oestradiol in vitro; in fact spermatogonia were unresponsive to hormonal stimulation. In addition, in short-term cultured testes, melatonin (at physiological
\end{abstract}

concentration) interferes with the effects of oestradiol on spermatogonial proliferation, supporting the hypothesis that melatonin exerts the inhibitory effect directly via its local action on the frog gonads. Morphological observation after in vivo or in vitro melatonin treatments indicates that Leydig cells display degenerative features, whereas in adjacent germinal tubules, Sertoli cells show heterochromatic nuclei. These results indicate that melatonin may act on Leydig cells and confirm that there is a paracrine interaction between interstitial and germinal compartments. The results of the present study indicate, for the first time, that melatonin may be directly involved in the inhibitory control of spermatogonial proliferation in the testis of the frog, $R$. esculenta.

\section{Introduction}

Primary spermatogonia in the frog Rana esculenta are very dynamic cells exhibiting a marked seasonal variation in the mitotic index ratio. It has been shown that, in the frog testis, the multiplication of primary spermatogonia is temperature dependent (Rastogi et al., 1985). In addition to high temperature, gonadotrophins and, to a certain extent, testosterone regulate the multiplication of primary spermatogonia (Rastogi et al., 1990). It is well known that $\mathrm{GnRH}$ and its long acting agonist, buserelin, directly stimulate androgen production and multiplication of primary spermatogonia in the frog testis (Minucci et al., 1986) and that oestradiol increases the mitotic index of primary spermatogonia via intratesticular mechanisms (Minucci et al., 1997). However, to date, there is no information concerning the effects of melatonin on the proliferation of primary spermatogonia. Melatonin, the primary hormone of the pineal gland, plays a key role in a variety of important physiological responses, including reproduction (Morgan et al., 1994).

*Correspondence

Email: sergio.minucci@unina2.it
In particular, melatonin provokes marked reproductive alterations in response to changes in daylength in seasonally breeding mammals (for reviews, see Reiter, 1991; Bartness et al., 1993). Several lines of evidence indicate that melatonin is involved in basic mechanisms that control cell proliferation and differentiation (Hill and Blask, 1988; Cos et al., 1991). Melatonin has a direct inhibitory effect on the proliferation of many types of cell (Persengiev and Kyurkchiev, 1993; Ying et al., 1993; Chen et al., 1995; Cos et al., 1996; Gilad et al., 1996; Petranka et al., 1999; Shiu et al., 1999), including the oestrogen-responsive MCF-7 human breast cancer cells (Liburdy et al., 1993; Crespo et al., 1994). In addition, Zhao et al. (2002) demonstrated that melatonin also inhibited the incorporation of $\left[{ }^{3} \mathrm{H}\right]$-thymidine in the rat uterine anti-mesometrial stromal cells, showing an antiproliferative effect on the uterus.

Considering that some preliminary investigations indicate a role for melatonin in inhibiting the multiplication of primary spermatogonia, in the present study the stathomokinetic method was used to determine the mitotic activity by using a metaphase arresting agent (colchicine) to examine whether there are any effects of the administration of melatonin alone or in combination 
with oestradiol on the mitotic activity of primary spermatogonia in the testis of the frog, $R$. esculenta.

\section{Materials and Methods}

\section{Animals}

Adult male frogs, $R$. esculenta, were captured during March (10 h light:14 h dark) and October (12 h light: $12 \mathrm{~h}$ dark) from the surroundings of Naples by a local dealer. The frogs were maintained in plastic tanks $(23 \mathrm{~cm} \times 16 \mathrm{~cm} \times 11 \mathrm{~cm}$ ) with water and food (meal worms) available ad libitum. Soon after capture or at the end of the experimental treatments, the frogs were killed by decapitation after anaesthesia with $1 \mathrm{~g}$ tricaine methane sulphonate (MS222) $\mathrm{I}^{-1}$ (Sigma, St Louis, MO).

\section{In vivo experiments}

The frogs were divided into two groups: (i) vehicle treated (amphibian Krebs' Ringer bicarbonate buffer, $\mathrm{pH} 7.4 ; \mathrm{KRB}, 100 \mu \mathrm{l})$ and (ii) melatonin (1 $\mu \mathrm{g}$ dissolved in $100 \mu \mathrm{K}$ KRB) treated. The injections were administered into the dorsal lymph sac during the scotophase. At $24 \mathrm{~h}$ after the start of the experiment the animals of each group were further divided for oestradiol treatment $(2 \mu \mathrm{g}$ oestradiol dissolved in $100 \mu \mathrm{KRR}$ ) as reported in Expts A and $B$ (see below). The frogs of each experimental group were killed at $24 \mathrm{~h}$ after the last oestradiol injection. All the frogs were injected with colchicine dissolved in KRB $(100 \mu \mathrm{g}$ per $100 \mu \mathrm{l}) 24 \mathrm{~h}$ before they were killed for the evaluation of the spermatogonial mitotic index.

Experiment $A$. The frogs $(n=40)$ of both vehicle- and melatonin-treated groups were further divided as follows: frogs $(n=5)$ that immediately received a single injection of oestradiol and frogs that also received a second injection of oestradiol $24 \mathrm{~h}$ later. The remaining frogs $(n=20)$ were used as untreated controls and melatonininjected groups at 24 and $48 \mathrm{~h}$.

Experiment B. The frogs $(n=30)$ of both vehicle- and melatonin-treated groups were further injected with a single dose of oestradiol immediately at $24 \mathrm{~h}$ and on day 7 after melatonin treatment. Five additional frogs were used as untreated initial controls $(0 \mathrm{~h})$.

\section{In vivo and in vitro experiments}

The frogs $(n=20)$ were divided into two groups: (i) vehicle treatment and (ii) melatonin treatment as in the in vivo experiments. At $24 \mathrm{~h}$ after the start of the experiment the frogs of each group were killed and each testis was cut in half and half of the testis was placed in a tube containing KRB alone, whereas the remaining half of the testis was placed in a tube containing KRB plus oestradiol $\left(10^{-6} \mathrm{~mol} \mathrm{I}^{-1}\right)$ for different time points $(6,12$ or $24 \mathrm{~h}$ ). For the evaluation of the spermatogonial mitotic index, colchicine $(50 \mu \mathrm{g})$ was added to the tubes of each group at $6 \mathrm{~h}$ before fixation. All the tubes were placed at room temperature $\left(20^{\circ} \mathrm{C}\right)$ in a shaking water bath and the incubation medium was replaced after $12 \mathrm{~h}$.

\section{In vitro experiments}

Experiment $A$. The frogs $(n=10)$ were decapitated and each testis was cut in half. Half testes of five animals were incubated in KRB alone or in KRB plus oestradiol $\left(10^{-6} \mathrm{~mol} \mathrm{I}^{-1}\right)$ for 6 or $12 \mathrm{~h}$. Half testes of the remaining five animals were used for incubations in KRB plus melatonin $\left(10^{-6} \mathrm{~mol} \mathrm{I}^{-1}\right)$ alone or in KRB plus melatonin $\left(10^{-6} \mathrm{~mol} \mathrm{I}^{-1}\right)$ plus oestradiol $\left(10^{-6} \mathrm{~mol} \mathrm{I}^{-1}\right)$, for the same times. All the tubes containing $50 \mu \mathrm{g}$ colchicine were placed at room temperature in a shaking water bath.

Experiment $B$. Five animals were killed and each testis was cut in half. Half of the testis of each animal was incubated for $6 \mathrm{~h}$ in a tube containing KRB plus oestradiol $\left(10^{-6} \mathrm{~mol} \mathrm{I}^{-1}\right)$, KRB plus melatonin $\left(10^{-6} \mathrm{~mol} \mathrm{I}^{-1}\right)$ plus oestradiol $\left(10^{-6} \mathrm{~mol} \mathrm{I}^{-1}\right)$, KRB plus melatonin $\left(10^{-9} \mathrm{~mol}\right.$ $\mathrm{I}^{-1}$ ) plus oestradiol $\left(10^{-6} \mathrm{~mol} \mathrm{I}^{-1}\right)$ or with KRB plus melatonin $\left(10^{-12} \mathrm{~mol} \mathrm{I}^{-1}\right)$ plus oestradiol $\left(10^{-6} \mathrm{~mol} \mathrm{I}^{-1}\right)$. All the tubes containing $50 \mu \mathrm{g}$ colchicine were placed at room temperature in a shaking water bath. Half testes of five additional animals were incubated in a tube containing only KRB in the presence of colchicine and were used as $6 \mathrm{~h}$ incubation controls.

\section{Histology and ultrastructure}

The testes were fixed by immersion in Bouin's fluid, dehydrated in ethanol, cleared in xylene and embedded in paraffin wax. Tissue sections ( $5 \mu \mathrm{m}$ ) were prepared and stained with haematoxylin-eosin for histological studies.

For electron microscopy, small pieces (approximately $1 \mathrm{~mm}^{3}$ ) of testis were fixed for $2 \mathrm{~h}$ at $4^{\circ} \mathrm{C}$ in Karnovsky's fluid $\left(0.1 \mathrm{~mol} \mathrm{I}^{-1}\right)$ at $\mathrm{pH} 7.4$ and post-fixed in $1 \%(\mathrm{w} / \mathrm{v})$ osmium tetroxide in the same buffer at $4^{\circ} \mathrm{C}$. Samples were then dehydrated in a graded series of ethanol and embedded in TAAB 812 (epoxy resin-araldite 812; TAAB Lab, Berkshire). Ultrathin sections were counterstained with $4 \%(\mathrm{w} / \mathrm{v})$ uranyl acetate followed by $1 \%(\mathrm{w} / \mathrm{v})$ lead citrate and observed under a Philips 301 transmission electron microscope.

\section{Statistical analysis}

Each value is the mean of five experimental animals. At least five sections, about $60 \mu \mathrm{m}$ apart from each testis, were used for quantitative analysis. The mitotic index of the primary spermatogonia was expressed as the number of metaphases $x$ total primary spermatogonia counted multiplied by 100 . All the data are expressed as mean with standard deviations. The groups were compared by 


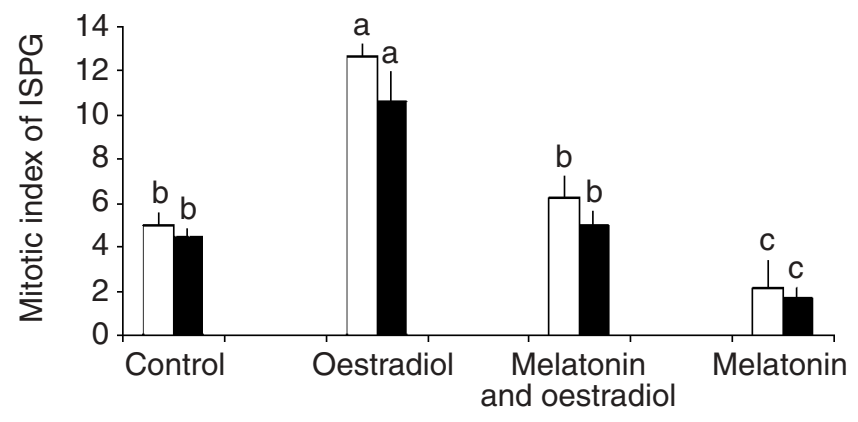

Fig. 1. In vivo effect of oestradiol, oestradiol administered in combination with melatonin and melatonin alone on the mitotic

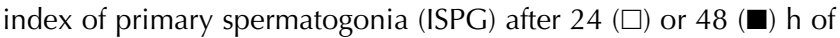
treatment in testes of frogs (Rana esculenta) captured during March. Values are $\pm \mathrm{SD}$, a versus b $P<0.01$, b versus $\mathrm{c} P<0.01$.

one-way ANOVA and Duncan's test (at $P<0.05$ and $P<$ 0.01) for multi-group comparisons.

\section{Results}

In vivo experiments

Experiment A. Testes obtained from frogs captured in March that were injected with oestradiol showed a significant increase in the mitotic index of primary spermatogonia at both 24 and $48 \mathrm{~h}$ in comparison with the untreated control testes (Fig. $1 ; P<0.01$ ). No significant differences were found in the testes of frogs injected with melatonin followed by oestradiol at 24 and $48 \mathrm{~h}$ before they were killed compared with testes of the untreated control testes (Fig. 1, $P<0.01$ ). The mitotic index of the primary spermatogonia evaluated in the testes of frogs exposed to melatonin alone was higher compared with the mitotic index of the untreated control testes at both 24 and $48 \mathrm{~h}$ (Fig. $1 ; P<0.01$ ). Morphological observations indicate that testes of the untreated control frogs showed the characteristic features for March. Testes are characterized by the presence of primary and secondary spermatogonia, and several cysts containing primary and secondary spermatocytes. Few spermatids and residual spermatozoa were found in the centre of the tubules. It is interesting to note that primary spermatogonia (the largest type of germ cell present in the adult testis) consisting of voluminous eosinophilic cytoplasm and usually an irregularly-shaped nucleus are distributed singly and located adjacent to the basement membrane of the seminiferous tubules, each associated with one to several Sertoli cells. Primary spermatogonia divide mitotically to give rise to either two daughter primary spermatogonia or through repeated divisions, form a germinal cyst composed of secondary spermatogonia.

The testis of a frog treated with oestradiol at $24 \mathrm{~h}$ showing several primary spermatogonia in metaphases in the germinal compartments is shown (Fig. 2).

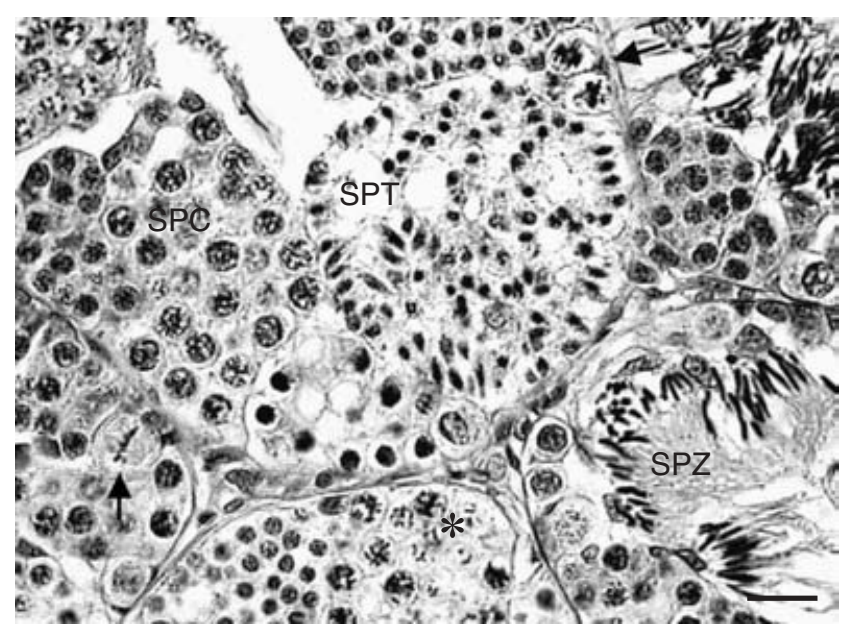

Fig. 2. Light micrograph showing primary spermatogonia (arrows) and secondary spermatogonia (asterisk) in metaphase in the testis of the frog (Rana esculenta) injected with oestradiol at $24 \mathrm{~h}$ after treatment. SPC: spermatocytes; SPT: spermatid; SPZ: spermatozoa. Scale bar represents $23 \mu \mathrm{m}$.
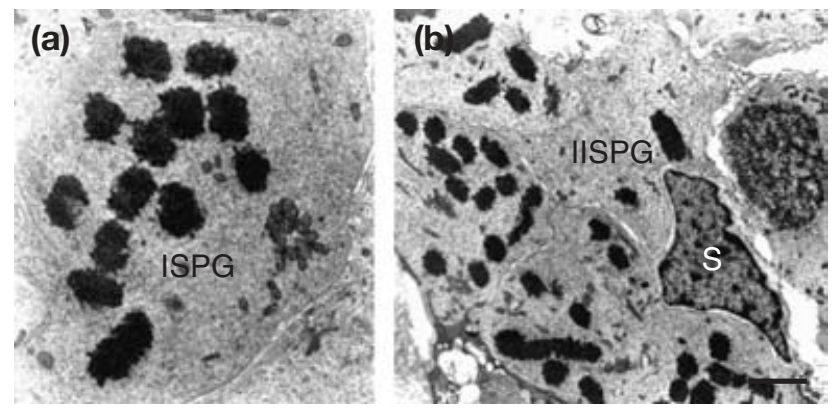

Fig. 3. Electron micrographs showing (a) a primary spermatogonia (ISPG) in metaphase and (b) a Sertoli cell (S) surrounding a nest of secondary spermatogonia (IISPG) in metaphase in the germinal compartment of the testis of the frog (Rana esculenta) at $24 \mathrm{~h}$ after oestradiol injection. Scale bars represent (a) $2 \mu \mathrm{m}$ and (b) $7 \mu \mathrm{m}$.

The electron micrographs of a primary spermatogonia and of a nest containing secondary spermatogonia that are surrounded by a Sertoli cell in metaphase in the testis of a frog treated with oestradiol at $24 \mathrm{~h}$ is shown (Fig. 3). In addition, in the testes of frogs treated with oestradiol both at 24 and $48 \mathrm{~h}$, germinal tubules surrounded by normal Leydig cells were of typical morphology and architecture with respect to Sertoli cells and germ cells under both the light (Fig. 4) and electron microscope. In contrast, in the interstitial compartment of frogs injected with melatonin alone or with melatonin plus oestradiol, at any time, many Leydig cells displayed heterochromatic nuclei, cytoplasmic fragmentation and loss of cellular adhesion. In the adjacent germinal compartment, several Sertoli cells showed heterochromatic nuclei (Fig. 5). The electron micrograph of a primary spermatogonia enveloped by a shrunken Sertoli cell observed in the 


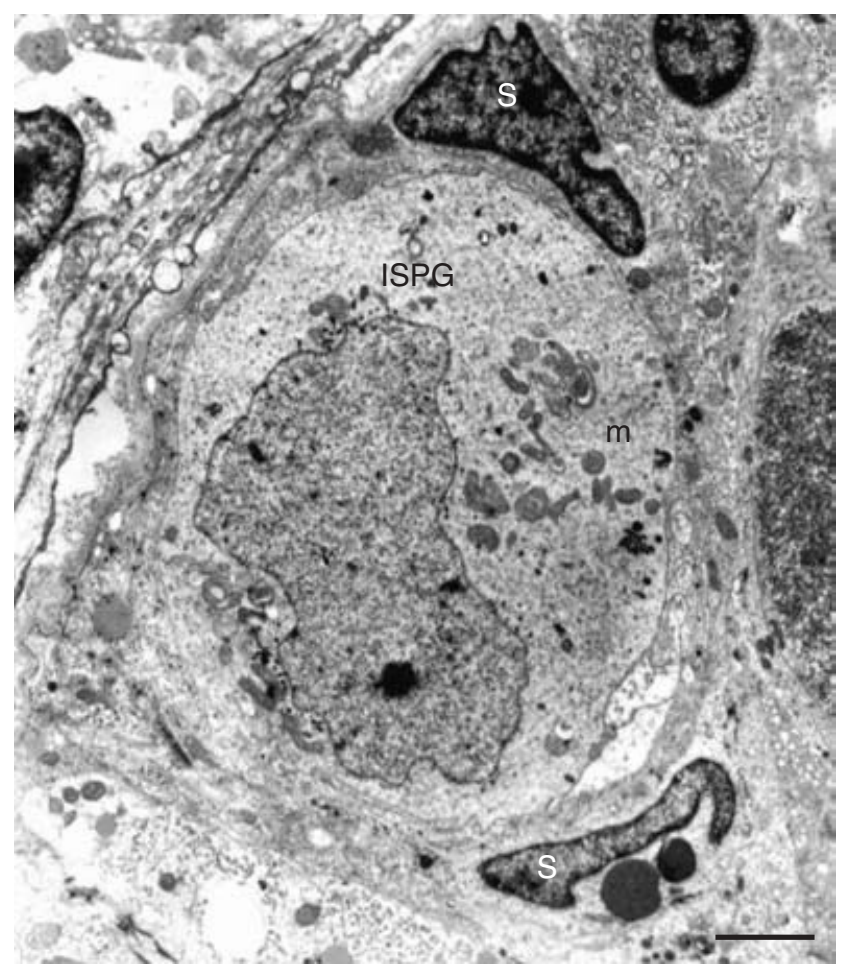

Fig. 4. Electron micrograph showing two Sertoli cells (S) adjacent to a primary spermatogonium (ISPG) in the testis of the frog (Rana esculenta) at $48 \mathrm{~h}$ after treatment with oestradiol. m: mitochondria. Scale bar represents $3 \mu \mathrm{m}$.

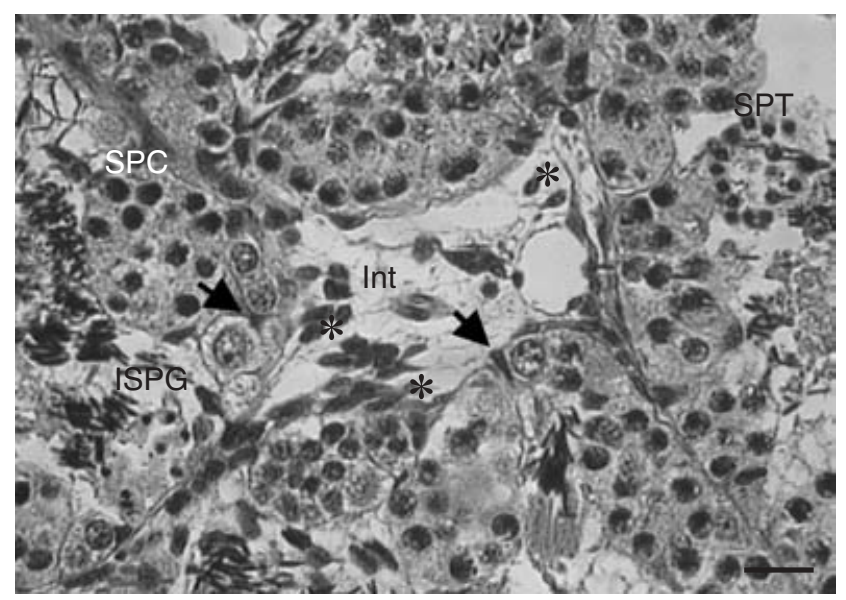

Fig. 5. Light micrograph showing many degenerate Leydig cells (asterisks) in interstitial tissue (Int) and several heterochromatic nuclei of Sertoli cells (arrows) adjacent to primary spermatogonia (ISPG) in the testis of the frog (Rana esculenta) at $24 \mathrm{~h}$ after melatonin injection. SPC: spermatocytes; SPT: spermatids. Scale bar represents $25 \mu \mathrm{m}$.

testis of a frog injected with melatonin after $48 \mathrm{~h}$ is shown (Fig. 6).

Experiment B. Testes of frogs captured during October that were injected with oestradiol showed a significantly higher mitotic index of primary spermatogonia either at

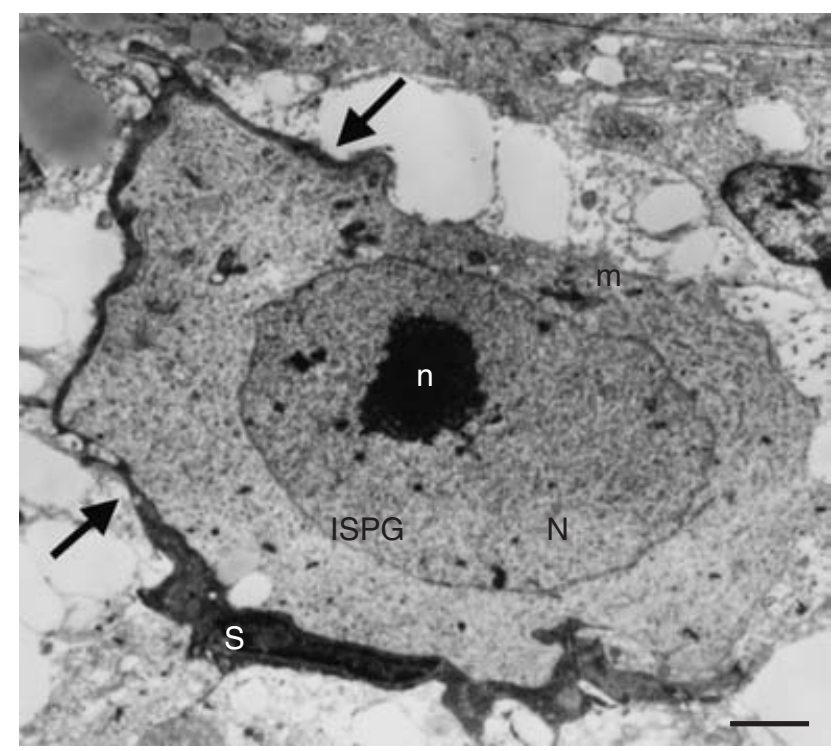

Fig. 6. Electron micrograph showing a primary spermatogonium (ISPG) enveloped by a shrunken Sertoli cell (arrows) in the testis of the frog (Rana esculenta) at $48 \mathrm{~h}$ after melatonin injection. $\mathrm{m}$ : Mitochondria; N: nucleus; n: nucleolus; S: Sertoli cell. Scale bar represents $2.5 \mu \mathrm{m}$.

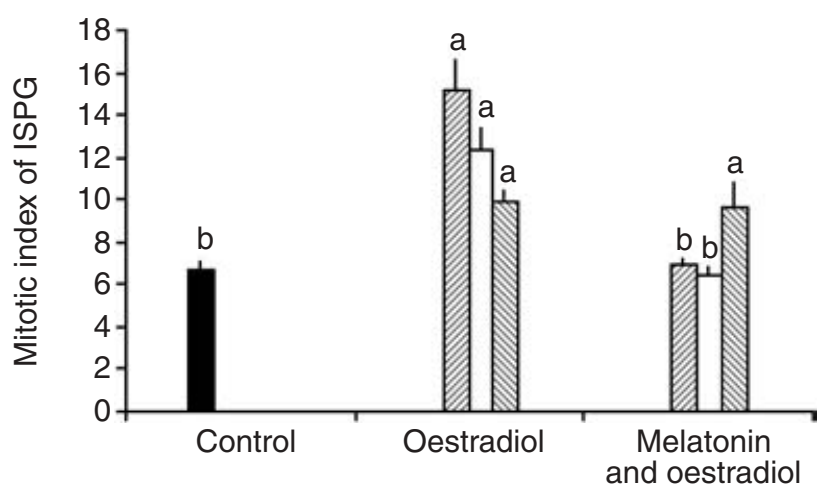

Fig. 7. In vivo effect of oestradiol and oestradiol administered in combination with melatonin on the mitotic index of the primary spermatogonia (ISPG) in the frog Rana esculenta. Frogs were injected with oestradiol plus colchicine or melatonin and then with a single dose of oestradiol plus colchicine immediately, at $24 \mathrm{~h}$ and on day 7 from the melatonin treatment. The animals were killed at $24 \mathrm{~h}$ after the last injection (24 h, $48 \mathrm{~h}$ and on day 8). Values are $\pm \mathrm{SD}$, a versus b $P<0.01$. $\mathbf{0}: 0 \mathrm{~h} ; \mathbb{E}: 48 \mathrm{~h} ; \square$ : 72 h; $\mathbb{\mathbb { N }}: 8$ days.

$48 \mathrm{~h}, 72 \mathrm{~h}$ or day 8 after treatment compared with the untreated control testes at $0 \mathrm{~h}(P<0.01$; Fig. 7). The increase in the mitotic index of primary spermatogonia is less pronounced at day 8 after the oestradiol injection.

No significant differences were found in the mitotic index of primary spermatogonia of frogs injected with melatonin and then with oestradiol at 48 and $72 \mathrm{~h}$ (Fig. 7). On the contrary, the mitotic index of primary spermatogonia observed in the testes of frogs treated with oestradiol on day 8 after the melatonin injection sharply 


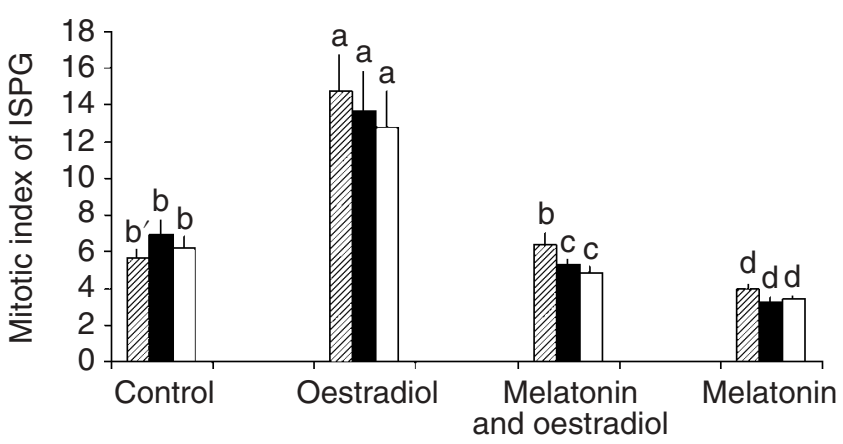

Fig. 8. In vitro effect of oestradiol $\left(10^{-6} \mathrm{~mol} \mathrm{I}^{-1}\right)$ on the mitotic

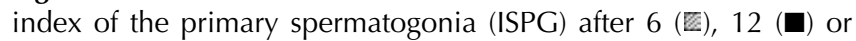
$24(\square) \mathrm{h}$ of incubation in testis of frogs captured in May that were injected with melatonin $(1 \mu \mathrm{g})$. Vertical bars indicate values $\pm \mathrm{SD}$, a versus $\mathrm{b}$ and $\mathrm{b}^{\prime} P<0.01, \mathrm{~b}$ versus $\mathrm{c} P<0.05, \mathrm{~b}^{\prime}$ and $\mathrm{b}$ versus $\mathrm{d} P<0.01$.

increased compared with those of the oestradiol-injected frogs at both 48 and $72 \mathrm{~h}$ (Fig. $7, P<0.01$ ).

\section{In vivo and in vitro experiments}

Testes of frogs captured in May that were incubated in medium containing oestradiol showed a significant increase in the mitotic index of primary spermatogonia by both 6 as well as 12 and $24 \mathrm{~h}$ of incubation as compared with untreated control testes (Fig. 8; $P<0.01$ ).

No significant differences were found in the mitotic index of primary spermatogonia observed in the testes of melatonin-treated animals incubated in medium containing oestradiol after $6 \mathrm{~h}$ as compared with that of the control testes at the same time (Fig. 8), whereas a small but significant decrease was observed at both 12 and $24 \mathrm{~h}$ of incubation as compared with that of the respective untreated control testes (Fig. 8; $P<0.05$ ). A significant decrease in the mitotic index of primary spermatogonia was observed in the testes of frogs that received melatonin alone as compared with that of the untreated control group at any time of incubation (Fig. 7; $P<0.01)$.

\section{In vitro experiments}

Experiment A. Testes of frogs captured in October that were exposed to oestradiol for 6 and $12 \mathrm{~h}$ showed a significant increase in the mitotic index of primary spermatogonia (Fig. 9; $P<0.01$ ). No differences were found in the mitotic index of primary spermatogonia of melatonin plus oestradiol-treated testis at both times of incubations as compared with that of the untreated control testes (Fig. 9).

The mitotic index of primary spermatogonia observed in the testes incubated in melatonin alone both at 6 or at $12 \mathrm{~h}$ of incubation was markedly lower in comparison with the values observed in the untreated control testes (Fig. 9; $P<0.01$ ).

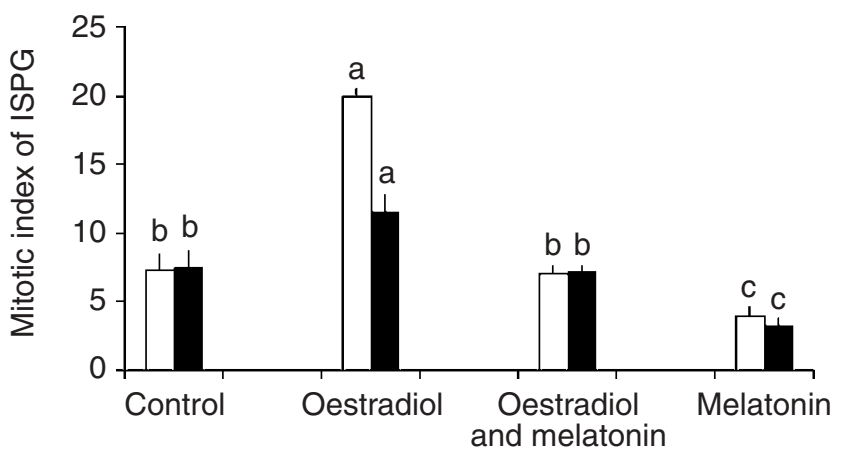

Fig. 9. In vitro effect of oestradiol $\left(10^{-6} \mathrm{~mol} \mathrm{I}^{-1}\right)$, oestradiol given in combination with melatonin $\left(10^{-6} \mathrm{~mol} \mathrm{I}^{-1}\right)$ and melatonin alone on the mitotic index of the primary spermatogonia (ISPG) after $6(\square)$ or $12(\square)$ h of incubation in testis of frogs captured in October. Values are $\pm \mathrm{SD}$, a versus $\mathrm{b} P<0.01$, b versus $\mathrm{c} P<0.01$.

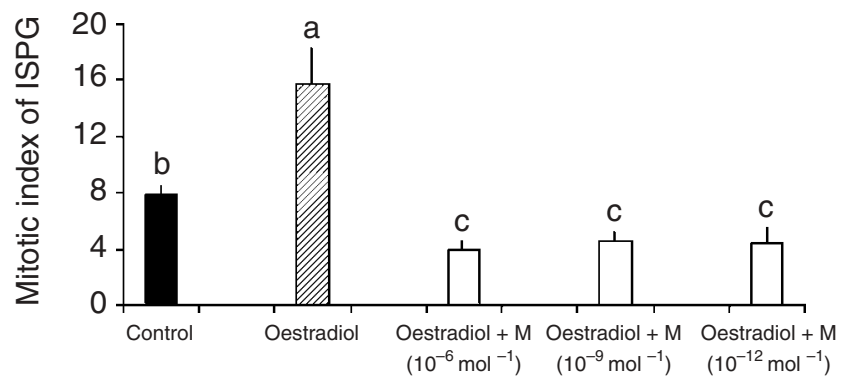

Fig. 10. In vitro effect of oestradiol $\left(10^{-6} \mathrm{~mol} \mathrm{I}^{-1}\right)$ and oestradiol given in combination with melatonin $(\mathrm{M})\left(10^{-6} \mathrm{~mol} \mathrm{I}^{-1}, 10^{-9}\right.$ $\mathrm{mol} \mathrm{I}^{-1}, 10^{-12} \mathrm{~mol} \mathrm{I}^{-1}$ ) on the mitotic index of the primary spermatogonia (ISPG) after $6 \mathrm{~h}$ of incubation in testis of frogs captured in October. Vertical bars indicate values \pm SD, a versus b $P<0.01$, a versus c $P<0.01$.

Experiment B. Testes of frogs captured in October that were incubated for $6 \mathrm{~h}$ in medium containing oestradiol alone showed a significant increase in the mitotic index of primary spermatogonia in comparison with the untreated control testes (Fig. 10; $P<0.01$ ), whereas the mitotic index of primary spermatogonia observed in the testes incubated in medium containing oestradiol and melatonin at any doses used $\left(10^{-6} \mathrm{~mol} \mathrm{I}^{-1}\right.$, $10^{-9} \mathrm{~mol} \mathrm{I}^{-1}$ and $10^{-12} \mathrm{~mol} \mathrm{I}^{-1}$ ) after $6 \mathrm{~h}$ of incubation was markedly lower as compared with that of the untreated control testes (Fig. 10).

\section{Discussion}

The gametogenic activity of the frog testis shows profound seasonal modifications that are closely correlated with the seasonal average number of primary spermatogonia. In addition, spermatogonial multiplication and differentiation into committed elements (Rastogi et al., 1985) appear to be required for active spermatogenesis in frogs.

Rastogi et al. (1978) have described the influence of temperature on spermatogenesis in frogs and, in 
particular, on the proliferative activity of primary spermatogonia. In addition, the proportion of cells in mitosis within the primary spermatogonia cell crop of the frog testis exhibits both seasonal and a daily rhythmic variation (Minucci et al., 1987). Several lines of evidence indicate that temperature represents the constraint which controls the responsiveness of primary spermatogonia to hormone factors (Rastogi et al., 1990) and that the mitotic activity of primary spermatogonia is modulated, synergistically, by gonadotrophins and testosterone (Rastogi et al., 1981, 1985; Minucci et al., 1992). In addition, the presence of spermatids seems to exert a negative intratesticular regulation of primary spermatogonia multiplication (Minucci et al., 1992).

In vertebrates, mitotic proliferation of germ cells seems to be dependent on several factors, including the stem cell factor and c-kit system (Sorrentino et al., 1988; Loveland and Schlatt, 1997; Munsie et al., 1997), GnRHlike substances (Minucci et al., 1986; Di Matteo et al., 1988) and oestradiol concentrations (Li et al., 1997; Minucci et al., 1997; Cobellis et al., 1999). In particular, there is accumulating evidence that oestrogens have a proliferative effect on rat and sea star gonocytes (March and Walker, 1995; Li et al., 1997; Walker et al., 1998). In addition, it has been demonstrated that oestradiol treatment increases mitotic activity of primary spermatogonia in the testis of the frog Rana esculenta (Minucci et al., 1997; Cobellis et al., 1999; this study) and these findings are in accordance with the strong mitogenic activity of spermatogonia detected during the annual reproductive cycle (Rastogi et al., 1985) in the period of the year characterized by the oestradiol peak (Varriale et al., 1986; Fasano et al., 1989).

Several studies have demonstrated the antiproliferative effects of melatonin using MCF7 cells as a model to study the anti-oestrogenic effect of this hormone (Hill and Blask, 1988; Wilson et al., 1992; Molis et al., 1994, 1995; Lissoni et al., 1995). Oestradiol was used in the present study to induce the spermatogonial proliferation to verify whether melatonin has an antioestrogenic role in the frog testis too. The results obtained from the in vivo experiments confirm that administration of oestradiol increases the mitotic index of primary spermatogonia within both 24 and $48 \mathrm{~h}$ of treatment. For the first time, these results indicate an inhibitory role for melatonin on proliferation of oestradiol-induced primary spermatogonia in the frog testis. This inhibitory effect ends on day 7 after melatonin injection, indicating that this inhibition is reversible. In addition, melatonin treatment also inhibited the mitotic index of primary spermatogonia in the testis of animals that were not injected with oestradiol.

It is well known that exposure to oestradiol induces an increase in the multiplication of primary spermatogonia in vitro too (Minucci et al., 1997). Moreover, testes from melatonin-injected animals, exposed to oestrogen in vitro, were unresponsive to hormonal stimulation.
These observations indicate that melatonin counteracts the increase in primary spermatogonia mitotic index induced in vitro by oestradiol.

The inhibitory effect exerted by melatonin on spermatogonial proliferation could be explained either through a mechanism involving the hypothalamic-pituitary gonadal axis or directly via the local action of indoleamine on the frog gonads. This last hypothesis is strongly supported by observations from experiments in vitro: in short-term cultured testes, melatonin at physiological concentration $\left(10^{-12} \mathrm{~mol} \mathrm{I}^{-1}\right)$ during the night interferes with the effects of oestradiol on proliferation of primary spermatogonia. Although these results clearly indicate that melatonin prevents an oestrogen-induced proliferation of primary spermatogonia, more data are needed to verify the mechanism of action of melatonin in the gonads. In fact, consideration should be given to the fact that melatonin interferes with the activation of the oestrogen receptor and destabilizes the binding of the oestradiol-oestrogen receptor complex to the oestrogen responsive element (Rato et al., 1999). Moreover, melatonin binding sites in the gonads of several vertebrate species have been demonstrated (Vera et al., 1997; Shiu et al., 2000; Clemens et al., 2001) and melatonin receptors coupled through a pertussis toxin-sensitive G-protein are present in adult rat Leydig cells (Valenti et al., 1997). In addition, the presence of a transcript of melatonin family receptors has been described in adult rat testis (De Rienzo et al., 2001).

After in vivo or in vitro melatonin treatments, many Leydig cells display degenerative features, whereas in the germinal compartment adjacent to them, several Sertoli cells show heterochromatic nuclei. This observation indicates that melatonin could act on Leydig cells and supports a paracrine interaction between interstitial and germinal compartments previously described after the administration of multiple ethane dimethane sulphonate injections, an alkylating agent which causes the degeneration of Leydig cells in several vertebrate testes (Minucci et al., 2000).

The possible action of melatonin on Leydig cells is supported in a study by Valenti et al. (1995) in which an acute inhibitory role of melatonin was confirmed on steroidogenesis of rat Leydig cells via reduced cAMP production. In addition, prolonged exposure to melatonin reduces the number and affinity of melatonin receptors on Leydig cell membranes and causes hypersensitization to $\mathrm{LH}$ challenge resulting in higher cAMP and testosterone secretion (Valenti et al., 2001). However, it has been demonstrated that in the Rana esculenta melatonin acts on the testis by modulating the $\mathrm{GnRH}$-induced androgen release (d'Istria et al., 2001).

In conclusion, the results of the present study show, for the first time, that melatonin interacts with the cellular proliferation of primary spermatogonia in the testis of Rana esculenta, indicating that it has a role in the regulation of frog spermatogenesis and, in particular, 
indicates that melatonin may have a direct inhibitory effect on the basal and oestradiol-stimulated mitotic activity of primary spermatogonia either in vivo or in vitro. Moreover, the results from the present study do not exclude an intratesticular regulative role of melatonin in the modulation of steroidogenesis activity that supports the progression of spermatogenesis.

The authors thank F. lamunno of the Stazione Zoologica 'A. Dohrn' (Naples, Italy) for his technical assistance and R. Barresi for the revision of the manuscript. This work was supported by the MIUR (ex 40\% 'Geremia' and ex 60\% 'Second University of Naples') grants.

\section{References}

Bartness TJ, Powers JB, Hastings MH, Bittman EL and Goldman BD (1993) The timed infusion paradigm for melatonin delivery: what has it taught us about the melatonin signal, its reception, and the photoperiodic control of seasonal responses? Journal of Pineal Research 15 161-190

Chen LD, Leal BZ, Reiter RJ, Abe M, Sewerynek E, Melchiorri D, Meitz ML and Poeggeler B (1995) Melatonin's inhibitory effect on growth of ME180 human cervical cancer cells is not related to intracellular glutathione concentrations Cancer Letters 91 153-159

Clemens JW, Jarzynka MJ and Witt-Enderby PA (2001) Down-regulation of $\mathrm{mt} 1$ melatonin receptors in rat ovary following estrogen exposure Life Science 69 27-35

Cobellis G, Pierantoni R, Minucci S, Pernas-Alonso R, Meccariello R and Fasano S (1999) C-fos activity in Rana esculenta testis: seasonal and estradiol-induced changes Endocrinology 140 3238-3244

Cos S, Blask DE, Lemus-Wilson A and Hill AB (1991) Effects of melatonin on the cell cycle kinetics and 'estrogen-rescue' of MCF-7 human breast cancer in culture Journal of Pineal Research 10 36-42

Cos S, Verduga R, Fernandez-Viadero C, Megias M and Crespo D (1996) Effects of melatonin on the proliferation and differentiation of human neuroblastoma cells in culture Neuroscience Letters 216 113-116

Crespo D, Fernandez-Viadero C, Verduga R, Ovejero V and Cos S (1994) Interaction between melatonin and estradiol on morphological and morphometric features of MCF-7 human breast cancer cells Journal of Pineal Research 16 215-222

De Rienzo G, Aniello F, Ferrara D, Minucci S, Serino I and d'Istria M (2001) Expression of MT1 and melatonin related receptor $(\mathrm{H} 9)$ in adult rat testis. In Perspective in Comparative Endocrinology: Unity and Diversity pp 1075-1079 Ed. Monduzzi

Di Matteo L, Minucci S, Fasano S, Pierantoni R, Varriale B and Chieffi G (1988) A gonadotropin-releasing hormone $(\mathrm{GnRH})$ antagonist decreases androgen production and spermatogonial multiplication in frog (Rana esculenta): indirect evidence for the existence of $\mathrm{GnRH}$ or $\mathrm{GnRH}$ like material receptors in the hypophysis and testis Endocrinology 122 $62-67$

d'Istria M, Fuschino A, Minucci S, Palmiero C, Rastogi RK and Serino I (2001) Melatonin effects on the testicular activity in the green frog, Rana esculenta. In Perspective in Comparative Endocrinology: Unity and Diversity pp 1089-1094 Ed. Monduzzi

Fasano S, Minucci S, Di Matteo L, D'Antonio M and Pierantoni R (1989) Intratesticular feedback mechanisms in the regulation of steroid profiles in the frog Rana esculenta. General and Comparative Endocrinology 75 335-342

Gilad E, Laudon M, Matzkin H, Pick E, Sofer M, Braf Z and Zisapel N (1996) Functional melatonin receptors in human prostate epithelial cells Endocrinology 137 1412-1417

Hill SM and Blask DE (1988) Effects of the pineal gland hormone melatonin on the proliferation and morphological characteristics of human breast cancer cells (MCF-7) in culture Cancer Research 48 6121-6126
Li H, Papadopoulos V, Vidic B, Dym M and Culty M (1997) Regulation of rat testis gonocyte proliferation by platelet-derived growth factor and estradiol: identification of signaling mechanisms involved Endocrinology 138 1289-1298

Liburdy RP, Sloma TR, Sokolic R and Yaswen P (1993) ELF magnetic fields, breast cancer, and melatonin: $60 \mathrm{~Hz}$ fields block melatonin's oncostatic action on $\mathrm{ER}^{+}$breast cancer cell proliferation Journal of Pineal Research 14 89-97

Lissoni P, Barni S, Meregalli S, Fossati V, Cazzaniga M, Esposti D and Tancini G (1995) Modulation of cancer endocrine therapy by melatonin: a phase II study of tamoxifen plus melatonin in metastatic breast cancer patients progressing under tamoxifen alone British Journal of Cancer $\mathbf{7 1}$ 854-856

Loveland KL and Schlatt S (1997) Stem cell factor and c-kit in the mammalian testis: lessons originating from Mother Nature's gene knockouts Journal of Endocrinology 153 337-344

Marsh AG and Walker CW (1995) Effect of estradiol and progesterone on c-myc expression in the sea star testis and the seasonal regulation of spermatogenesis Molecular Reproduction Development 40 62-68

Minucci S, Di Matteo L, Pierantoni R, Varriale B, Rastogi RK and Chieffi G (1986) In vivo and in vitro stimulatory effect of a gonadotropin-releasing hormone analog (HOE 766) on spermatogonial multiplication in the frog, Rana esculenta. Endocrinology 119 731-736

Minucci S, Di Matteo L, Di Meglio M and Rastogi RK (1987) Circadian variation in mitotic index of primary spermatogonia in the adult frog (Rana esculenta) Bollettino di Zoolgia 54 87-89

Minucci S, Di Matteo L, Fasano S, Chieffi Baccari G and Pierantoni R (1992) Intratesticular control of spermatogenesis in the frog, Rana esculenta. Journal of Experimental Zoology 264 113-118

Minucci S, Di Matteo L, Chieffi P, Pierantoni R and Fasano S (1997) $17 \beta$ estradiol effects on mast cell number and spermatogonial mitotic index in the testis of the frog, Rana esculenta. Journal of Experimental Zoology 278 93-100

Minucci S, De Rienzo G, Di Sena R, Cobellis G, Meccariello R, Pierantoni $\mathbf{R}$ and Fasano $\mathbf{S}$ (2000) Effect of multiple injections of ethane-1,2dimethane sulphonate (EDS) on the frog, Rana esculenta testicular activity Journal of Experimental Zoology 287 384-393

Molis TM, Spriggs LL and Hill SM (1994) Modulation of estrogen receptor mRNA expression by melatonin in MCF-7 human breast cancer cells Molecular Endocrinology 8 1681-1690

Molis TM, Spriggs LL, Jupiter Y and Hill SM (1995) Melatonin modulation of estrogen-regulated proteins growth factors and proto-oncogenes in human breast cancer Journal of Pineal Research 18 93-103

Morgan PJ, Barrett P, Howell HE and Helliwell R (1994) Melatonin receptors: localization, molecular pharmacology and physiological significance Neurochemistry International 24 101-146 Review

Munsie M, Schlatt S, de Krester DM and Loveland KL (1997) Expression of stem cell factor in the postnatal rat testis Molecular Reproduction and Development 47 19-25

Persengiev SP and Kyurkchiev S (1993) Selective effect of melatonin on the proliferation of lymphoid cells International Journal of Biochemistry $\mathbf{2 5}$ 441-444

Petranka J, Baldwin W, Biermann J, Jayadev S, Barrett JC and Murphy E (1999) The oncostatic action of melatonin in an ovarian carcinoma cell line Journal of Pineal Research 26 129-136

Rastogi RK, Iela L, Delrio G, Di Meglio M, Russo A and Chieffi G (1978) Environmental influence on testicular activity in the green frog, Rana esculenta. Journal of Experimental Zoology 206 49-64

Rastogi RK, Tammaro L, Di Meglio M, Iela L, Di Matteo L and Chieffi G (1981) Circannual testicular rhythm in the green frog, Rana esculenta. Bollettino di Zoologia 48 97-105

Rastogi RK, Di Meglio M, Di Matteo L, Minucci S and Iela L (1985) Morphology and cell population kinetics of primary spermatogonia in the frog (Rana esculenta) (Amphibia: Anura) Journal of Zoology London (A) 207 319-330

Rastogi RK, Di Matteo L, Minucci S, Di Meglio M and Iela L (1990) Regulation of primary spermatogonial proliferation in the frog (Rana esculenta): an experimental analysis Journal of Zoology London $\mathbf{2 2 0}$ 201-211 
Rato AG, Pedrero JG, Martinez MA, del Rio B, Lazo PS and Ramos S (1999) Melatonin blocks the activation of estrogen receptor for DNA binding FASEB Journal 13 857-868

Reiter RJ (1991) Pineal melatonin: cell biology of its synthesis and of its physiological interactions Endocrine Reviews 12 151-180 Review

Shiu SY, Li L, Xu JN, Pang CS, Wong JTY and Pang SF (1999) Melatonininduced inhibition of proliferation and $\mathrm{G} 1 / \mathrm{S}$ cell cycle transition delay of human choriocarcinoma Jar cells: possible involvement of MT2 (MEL1B) receptor Journal of Pineal Research 27 183-19

Shiu SY, Li L, Siu SW, Xi SC, Fong SW and Pang SF (2000) Biological basis and possible physiological implications of melatonin receptor-mediated signaling in the rat epididymis Biological Signals and Receptors 9172 187 Review

Sorrentino V, McKinney MD, Giorgi M, Geremia R and Fleissner E (1988) Expression of cellular protooncogenes in the mouse male germ line: a distinctive 2,4-kb pim-1 transcript is expressed in haploid post meiotic cells Proceedings National Academy of Science USA 85 2191-2195

Valenti S, Guido R, Giusti M and Giordano G (1995) In vitro acute and prolonged effects of melatonin on purified rat Leydig cell steroidogenesis and adenosine $3^{\prime}, 5^{\prime}$-monophospate production Endocrinology 136 5357-5362

Valenti S, Giusti M, Guido R and Giordano G (1997) Melatonin receptors are present in adult rat Leydig cells and are coupled through a pertussis toxin-sensitive G-protein European Journal of Endocrinology 136633 639

Valenti S, Fazzuoli L, Giordano G and Giusti M (2001) Changes in binding of iodomelatonin to membranes of Leydig cells and steroidogenesis after prolonged in vitro exposure to melatonin International Journal of Andrology 24 80-86
Varriale B, Pierantoni R, Di Matteo L, Minucci S, Fasano S, D'Antonio M and Chieffi G (1986) Plasma and testicular estradiol and plasma androgen profile in the male frog Rana esculenta during the annual cycle General Comparative Endocrinology 64 401-404

Vera H, Tijmes M and Valladares LE (1997) Melatonin and testicular function: characterization of binding sites for $2-\left[{ }^{125} \mathrm{I}\right]$-iodomelatonin in immature rat testes Steroids 62 226-229

Walker CW, Demian DJ, Kirby PJ, Blickarz CE and Hallonquist $\mathbf{H}$ (1998) Interacting mitogenic pathways during spermatogonial G1/Sphase traverse in the sea star, Asterias Vulgaris. Annals - New York Academy of Science 839 321-325

Wilson ST, Blask DE and Lemus-Wilson AM (1992) Melatonin augments the sensitivity of MCF-7 human breast cancer cells to tamoxifen in vitro. Journal of Clinical Endocrinology and Metabolism 75 669-670

Ying SW, Niles LP and Crocker C (1993) Human malignant melanoma cells express high-affinity receptors for melatonin: antiproliferative effects of melatonin and 6-chloromelatonin European Journal of Pharmacology 246 89-96

Zhao H, Pang SF and Poon AMS (2002) MT1 receptor-mediated antiproliferative effects of melatonin on the rat uterine antimesometrial stromal cells Molecular Reproduction and Development 61 192-199

Received 20 January 2003

First decision 5 March 2003

Revised manuscript received 19 March 2003.

Accepted 9 April 2003. 